EISSN - 2182-8407

Sociedade Portuguesa de Psicologia da Saúde - SPPS - www.sp-ps.com

DOI: http://dx.doi.org/10.15309/14psd150210

\title{
BONDING AND PREMATURITY: EXPLORATORY STUDY ON EARLY PATERNAL INVOLVEMENT IN HOSPITALIZATION CONTEXTS
}

\author{
Isabel Leal ${ }^{1,2}$ ॠ , Nuno Saldanha ${ }^{1}$, \& Raquel V. Oliveira ${ }^{2}$ \\ ${ }^{1}$ ISPA - Instituto Universitário; ${ }^{2}$ UIPES - Research Unit in Psychology and Health - \\ $\mathrm{R} \& \mathrm{D}$
}

\begin{abstract}
The father's role in the modern family has been less studied and is poorly defined in the literature. Through an interview and qualitative analysis, we intend to explore paternal involvement in the context of hospitalization due to premature childbirth. This is exploratory and transversal study. We used semi-structured interviews to evaluate the emotional involvement of five parents with their children. Content analysis was used to analyse the interviews. The results revealed there are favourable conditions to make paternal involvement possible and beneficial for both father and child. The involvement appeared to be multidimensional and was subsequently classified as positive in this research. These fathers considered that early involvement/bonding with the premature baby was crucial for the future of their relationship. The condition of hospitalization for preterm birth seems to be a situation that, although hard and anxiogenic, also offers possibilities for contact and father involvement with the new-born.
\end{abstract}

Key- words - bonding, content analysis, early relationship, fatherhood, paternal involvement, prematurity.

\section{BONDING E PREMATURIDADE: ESTUDO EXPLORATÓRIO SOBRE O ENVOLVIMENTO PATERNO EM CONTEXTO HOSPITALAR}

RESUMO- O papel do pai na família moderna tem sido pouco estudado e mal é definido na literatura. Através de uma entrevista e análise qualitativa, explora-se o envolvimento paterno no contexto de hospitalização devido ao parto prematuro. Este é um estudo exploratório e transversal em que se usou entrevistas semi-estruturadas para avaliar o envolvimento emocional de cinco pais com seus filhos. A análise de conteúdo foi usada para analisar as entrevistas. Os resultados revelaram que existem condições favoráveis para tornar o envolvimento paterno possível e benéfico para ambos, pai e filho. $\mathrm{O}$ envolvimento paterno surge aqui como multidimensional. Os pais consideram esse envolvimento precoce/ligação com o bebé prematuro como crucial para o futuro da relação deles. A condição de hospitalização por parto prematuro parece ser uma situação que, embora difícil e anxiogénica, oferece possibilidades para o contacto e o envolvimento paterno com o bebé recém-nascido.

Recebido em 26 de Setembro de 2013/ Aceite em 9 de Junho de 2014

\footnotetext{
- Rua Jardim do Tabaco, 34, 1149 - 041 Lisboa. Tel: +351218811700; Fax: +351218860954. E-mail: ileal@ispa.pt
} 
Until recently, the usual presence of mothers as primary caregivers has promoted the implicit idea that the father-child relationship would have little impact on children's development (Cabrera \& Tamis-LeMonda, 2000). Valued mainly for their financial and instrumental support, men have frequently been given the role of second object or first stranger (Liebman \& Abell, 2000), often being called the forgotten parent (Ross, 1979). The father figure has been represented in an imprecise and ambiguous way, distorted by several studies in which the relationship and the father's presence are evaluated by theories originally conceived to study the relationship between mother and child (Ford, Nalbone, Wetchler, \& Sutton, 2008; McBride, Dyer, Liu, Brown, \& Hong, 2009). Despite the fact that previous research has focused almost exclusively on the mother-child relationship, the role of the father as a caregiver and the specificities of his physical and emotional involvement with the child have been a source of special interest, both in the scientific community and society in general (Fägerskiöld, 2008; Lamb, 1986; Premberg, Hellström, \& Berg, 2008).

In recent years, fatherhood has become an important focus both in research and in the development of new public policies (Robb, 2004). As Robb refers "there is a need for such policy and practice initiatives to be informed by up-to-date research about men's experience of fatherhood, particularly at a time of considerable change in both perceptions and experiences in this area" (Robb, 2004, p. 395). The author further emphasizes that most of the studies developed regarding fatherhood have focused, not on the father's experience, but rather on the impact of the father's involvement on the child's development, which may lead to inadequate policies and practice (Robb, 2004).

Therefore, it can be stated that fatherhood is a concept that has been changing drastically over the last few decades in the sense that fathers are getting closer to their children, interacting with them, and appearing interested and strongly active in their education (Camus \& Frascarolo, 2003; Lindberg, Axelsson, \& Öhrling, 2008). There are, in fact, several studies with results showing a more effective and affective paternal involvement (Fägerskiöld, 2006; Hossain, Roopnarine, Ismail, Hashmi, \& Sombuling, 2007), showing that fathers desire to be present during the growth and development of their children. This change in the role of the father is multidimensional and encompasses several aspects, such as direct care provided to the child at any age (Camus \& Frascarolo, 2003; Lamb, 1986; Lindberg et al., 2008; Simões, Leal, \& Maroco, 2010).

Paternal involvement, is defined in terms of the time spent and the quality of the interaction with the child (Adamsons, O’Brien, \& Pasley, 2007; Featherstone, 2004). The necessity to develop comprehensive and multidimensional conceptualizations of paternal involvement has been increasingly advocated. One of the most influential models is that of Lamb, Pleck, and Charnov (1985), which distinguishes three components of the father's involvement: direct interaction (time spent taking care of, or interacting, with the child); accessibility (time spent in activities requiring a lower degree of interaction, but that require the father's availability for the child); and responsibility (essential tasks for the wellbeing, care and safety of the child).

Bonding requires the existence of early physical contact that acts as a catalyst to the whole process, which is crucial for the baby's development (Peterson, 2008; Ringler, Trause, Klaus, \& Kennell, 1978). The few studies done with the father figure show a positive impact on emotional involvement and on the quality of the interaction between father and child in cases 
where there is early contact with the baby (Fegran, Helseth, \& Fagermoen, 2008; Feldman, Weller, Sirota, \& Eidelman, 2003; Pestvenidze \& Bohrer, 2007). The physical/bodily proximity is crucial for the development of a connection between father and child and it precedes the establishment of a relationship, so the father can and should be present since the early days after birth (Arockiasamy, Holsti, \& Albersheim, 2008; Camus \& Frascarolo, 2003; Fegran et al., 2008).

The preterm birth and subsequent hospitalization of the baby have a huge emotional impact on the parents and disrupt the bonding and involvement process between father and child (Fegran et al., 2008; Jotzo \& Poets, 2005; Lau \& Morse, 2003). Despite the difficulties felt in these conditions, the father seems to be prepared for involvement and interaction with his child since the birth (Lindberg et al., 2008). This strong emotional impact associated with the desire of interaction may lead to ambivalent feelings in the first contact the parent has with the new-born (Fegran et al., 2008). The preterm situation represents a specific moment of family crisis, and its impact on the father/child relationship is still not fully explored and researched (Lau \& Morse, 2003). It is, therefore, necessary to intensify the research in the area of preterm birth, especially when it comes to early fatherly involvement.

Given the lack of research regarding the father's early involvement, even more so in crisis situations, and the need for more in-depth studies taking into account the father's own experience, we conducted this study in order to explore early paternal involvement in cases of preterm childbirth.

In this way, the aim of this study was to explore the specificity of the father's involvement in a context of preterm hospitalization, to assess the different aspects that surrounded the pregnancy and preterm delivery namely the father's emotional involvement with the baby in the context of hospitalization for preterm birth; the specificities of the father's emotional involvement with the baby, based on the four factors affecting parental involvement (Motivation, Self-confidence, Support and Institutional Practices) (Lamb et al., 1985); and the ideas regarding paternal involvement, and beliefs fathers have about their own involvement.

\section{METHOD}

We developed a exploratory and transversal study. Content analysis was used as the data analysis instrument.

\section{Participants}

For the purpose of this investigation, five fathers of preterm babies hospitalized in the Neonatology Unit at São Francisco Xavier Hospital (Lisbon, Portugal) were interviewed. All participants' met the inclusion criteria: being male, father of a preterm baby (24-35 weeks), with a minimum of three visits to the baby before the interview.

The participants were between the ages of 28 and 39 years. They all had a permanent job and were married $(n=3)$ or cohabiting $(n=2)$ with the child's mother, and two had other 
children. The babies of the study were born between 24 and 34 weeks with weights ranging between 710 grams and 3,85 Kg.

Three babies were born by caesarean section and two babies were born via vaginal birth.

\section{Materials}

In this study, a clinical semi-structured interview with 17 open-ended questions was used to explore the emotional involvement of the participants. The interview was developed using non-directive questions, in order to elicit a fluent narrative on the participant's actual experience, which were clear and simply formulated in order to be understood by participants from any social and educational background (Lamb, Orbahc, Hershkowitz, Esplin, \& Horowitz, 2007; Leal, 2008; Oliveira, Maroco, \& Pais, 2012).

A socio-demographic and clinical questionnaire, with 16 direct questions, was also developed to enable the characterization of the fathers, the babies and of the pre and postpartum period.

\section{Procedure}

This research project was approved by the Ethics committee of São Xavier's Hospital board. After approval, selection of the participants through a convenience sampling was performed (all fathers that fulfilled the inclusion criteria were contacted) and the first contact established. The study was presented and the context of the research explained. The fathers who had agreed to participate in the study gave their informed consent accordingly with the hospital rules and the law. The interviews were conducted, at a previously scheduled time, each lasting 45 minutes. A complete and integral transcript of each interview was prepared. The interviews' transcripts were analysed using Bardin's (2008) content analysis techniques.

To ensure the validity and reliability, the authors coded the data twice (in two separate points in time), and two independent judges helped stabilize the categories (i.e., they independently re-coded the material in order to ensure that the categories were adequately defined, allowing the reproducibility of the study, and allowing to determine consensus in coding the material). There was a high consensus between researchers and judges, with the disagreements solved by returning to the transcripts (Bardin, 2008). After the final categorization, the data were analysed and interpreted in light of the theoretical framework.

\section{RESULTS}

The fathers' responses were grouped into six main themes (pre-categories), as can be seen in Table 1. The content analysis further originated 15 categories, totalizing 338 recording units (r.u.) (see Table 1). 
Table 1.

Content analysis’ pre-categories, categories and sub-categories

\begin{tabular}{|c|c|c|c|}
\hline Pre-Categories & Categories & $\begin{array}{l}\text { Recording } \\
\text { Units }\end{array}$ & $\begin{array}{l}\text { Recording } \\
\text { units }\end{array}$ \\
\hline \multirow{2}{*}{$\begin{array}{l}\text { A - Support } \\
\text { Matrix }\end{array}$} & $\begin{array}{l}\text { A1 - Characterization and Relationship with } \\
\text { the partner/mother of the baby }\end{array}$ & 19 & \multirow[t]{2}{*}{30} \\
\hline & $\begin{array}{l}\text { A2 - Characterization and relationship } \\
\text { with the remaining family }\end{array}$ & 11 & \\
\hline \multirow{4}{*}{$\begin{array}{l}\text { B - Feelings and } \\
\text { reactions before } \\
\text { childbirth }\end{array}$} & B1 - Context in which the baby appeared & 9 & \multirow[t]{4}{*}{62} \\
\hline & $\begin{array}{l}\text { B2 - Reaction and/or feelings towards } \\
\text { the news and course of the pregnancy }\end{array}$ & 17 & \\
\hline & $\begin{array}{l}\text { B3 - Feelings towards the perspective of } \\
\text { being a father }\end{array}$ & 12 & \\
\hline & B4 - Imaginary baby & 24 & \\
\hline \multirow{2}{*}{$\begin{array}{l}\mathrm{C} \text { - Feelings and } \\
\text { reactions after } \\
\text { childbirth }\end{array}$} & $\begin{array}{l}\text { C1 - Feelings during and after the birth of the } \\
\text { baby }\end{array}$ & 17 & \multirow[t]{2}{*}{28} \\
\hline & $\begin{array}{l}\text { C2 - Feelings after seeing the baby for } \\
\text { the first time }\end{array}$ & 11 & \\
\hline \multirow{4}{*}{$\begin{array}{l}\text { D - Involvement } \\
\text { with the baby }\end{array}$} & $\begin{array}{l}\text { D1 - Present feelings and dreams about the } \\
\text { baby }\end{array}$ & 48 & \multirow[t]{4}{*}{143} \\
\hline & $\begin{array}{l}\text { D2 - Characteristics and/or peculiarities } \\
\text { of the baby }\end{array}$ & 18 & \\
\hline & $\begin{array}{l}\text { D3 - Willingness and motivation to } \\
\text { interact and get involved with the baby }\end{array}$ & 32 & \\
\hline & D4 - Actual interaction with the baby & 45 & \\
\hline \multirow{3}{*}{$\begin{array}{l}\text { E - Feelings } \\
\text { towards } \\
\text { fatherhood }\end{array}$} & $\begin{array}{l}\text { E1 - Feeling towards parenthood and self- } \\
\text { characterization as a father }\end{array}$ & 19 & \multirow[t]{3}{*}{46} \\
\hline & $\begin{array}{l}\text { E2 - Opinion on the early paternal } \\
\text { involvement }\end{array}$ & 17 & \\
\hline & $\begin{array}{l}\text { E3 - Opinion of the partner about the } \\
\text { early paternal emotional involvement }\end{array}$ & 10 & \\
\hline \multicolumn{2}{|c|}{$\begin{array}{l}\text { F - Concerns about the health of the baby, clinical issues and } \\
\text { medical involvement }\end{array}$} & 32 & \\
\hline \multicolumn{2}{|l|}{ TOTAL } & 341 & \\
\hline
\end{tabular}

Table 1 shows that the Pre-category with the highest number of recording units (r.u) is "Involvement with the baby" ( $\mathrm{D}=143$ r.u.), being followed by "Feelings and reactions before childbirth" (B = 62 r.u.), "Feelings towards fatherhood" ( $E=46$ r.u.), "Concerns about the baby's health, clinical issues and medical involvement" ( $\mathrm{F}=32$ r.u.), "Support matrix" (A = 30 r.u.), and finally "Feelings and reactions after childbirth" (C = 28 r.u.). 
Within the first pre-category, two categories arose "Characterization and Relationship with the partner/mother of the baby" and "Characterization and relationship with the remaining family". All the participants classified their relationship with the partner/mother of the baby as very good, being somewhat idealized:

"Very good... Really, really good. Perfect dialogue, regular work, no stress, no fighting, perfect... any better would be impossible" (A3)

Nevertheless, some participants reported difficulties in the relationship related to the difficulties felt due to the pre-term birth:

"There was a time when we were a bit confused, lost even" (A2)

Regarding the relationships with the rest of the family, these were mostly characterized as positive, presenting a lower number of r.u.; two of the participants emphasized the relationship with their other children, and one participant reported conflicts between members of the extended family. However, only one of the participants talked about the importance of family support:

"The time that we cannot be here, we are with our daughter, we also have to share it with her" (A2)

The second pre-category, "Feelings and reactions before childbirth", included four categories the "Context in which the baby appeared" which presented the lowest r.u. frequency (B1 = 9), "Reaction and/or feelings towards the news and course of the pregnancy", "Feelings towards the perspective of being a father" and "Imaginary baby", being this last category the one with the highest r.u. number. Regarding the planning of the pregnancy, although it was only planned in two cases, all the participants reported it was a desired pregnancy:

"He wasn't planned but was very desired" (A1);

"It was a planned pregnancy, $P$. wanted it very much and so did I" (A4).

As for the reaction and feelings towards the pregnancy, all the participants reported feeling happy with the news:

"When I found out I felt happy, very happy" (A1).

However, these feelings became conflictual during the pregnancy in some cases, due to difficulties that occurred (monetary, medical):

"[after the $22^{\text {nd }}$ week it was complicated] and from there on it was a mixture of feelings of... concern, what could happen, right?” (A2).

All the participants were happy and felt accomplished with the possibility of becoming fathers, although some also felt nervous:

"Aaaa... Maybe a bit nervous... not knowing if I am already prepared" (A1)

Regarding the imaginary baby, two participants denied having imagined the baby during the pregnancy:

"I did not imagine. Do not like those things ... then there are lot of expectations... and that creates a problem" (A5).

However, one of these parents ended up mentioning how he had expected the baby to be during the pregnancy: 
"At the time thought he would be blond or bald..." (A1).

The other three fathers declared having imagined and fantasized about the baby during the pregnancy period:

"But from the moment she started... and she was pregnant... I did not even know if it was male or female, I fantasized immediately" (A3).

The pre-category $\mathrm{C}$ incorporated two categories "Feelings during and after childbirth" and "Feelings after seeing the baby for the first time" (C1 = 17 r.u, C2 $=11$ r.u). In this precategory the participants reported very ambiguous and conflictual feelings. Regarding childbirth, the participants reported on the one hand feelings of happiness and joy due to the birth of the baby and on the other sadness and worry because it was a premature birth:

"It was ... It was like I was saying... a swirl of emotions... because... it is logical that I felt very happy because.... they were already born but I was also a bit worried because they were born too soon..." (A2).

One of these parents had enhanced feelings of sadness and anguish that were associated with the death of one of the babies:

"[ended up, dying ...] aaaa, it is obvious that I cried a lot, I was here in this room for a long time, we were completely desperate" (A2).

Concerning the first time they saw the baby the feelings described were equally ambiguous: three participants referred feeling joy, and two reported sadness and worry at the sight of such a fragile baby:

"Very proud, very happy..." (A5);

"I cried a lot because he is very fragile, very tiny, like a mosquito inside there (...) it was bad, not like I had imagined" (A3).

The pre-category "Involvement with the baby" was the one that presented the highest r.u. number, being that D1, D3 and D4 were the categories with the highest r.u. frequencies; thus the fathers described more the "present feelings and dreams about the baby", their "actual interaction with the baby" and the "willingness and motivation to interact and get involved with the baby". Also included in this pre-category, but with a lower number of r.u., was the category "characteristics and/or peculiarities of the baby" (D2 = 18 r.u.). Most parents continue reporting ambiguous feelings and emotions at this point, as they are happy because the baby is recovering, but still feel anxious and scared that the baby's medical condition may yet worsen:

“Ah, now... I'm calmer, right? Regarding him I already feel much better... I pick him up, I feel... more comfortable... Of course, I am still scared that something might happen tomorrow, but I am prepared" (A3).

Some fathers also report dreaming about the baby: two of them had nightmares or agitated dreams about the hospitalization/future of the baby; one had pleasant dreams in which he performed several activities with the baby, while another father alternated between nightmares and pleasant dreams:

"Oh yes... I have dreamt...nice dreams... sometimes not so good... because... well... perhaps due to all this... I dream a lot, I dream a lot" (A1). 
In terms of characterization of their babies, the fathers talked mostly about physical features

"Yeah... He has tiny little ears, the eyes are light... He will have light eyes too... It's the greatest peculiarity... and he has big hands. He also has a lot of hair" (A5).

Moreover, two fathers mentioned psychological and/or personality features to describe their baby

"He has a strong personality...It is difficult" (A1).

Furthermore, all the participants described being motivated and wanting to interact with their babies, especially to be able to perform everyday life activities with their children

"Everything. To play with him, give him the bottle, put him to sleep... walk... At the moment, all these things that involve all of that contact. To see him smile..." (A1).

As for the actual interaction with the baby, all the participants described visiting the baby every day or every time they can:

"I've been here every day since he was born..." (A5).

They describe the interaction as positive, as they try to interact as much as possible with the baby, but somewhat limited due to the incubator (physical barrier) or to the baby's health:

"I communicate with him, put my hand inside, I touch his little hands, his feet... I try to touch him as much as possible... of course I cannot touch him for too much time, because the air, the hot air comes out..." (A3).

As for the pre-category "Feelings towards fatherhood", it includes the category "feeling towards parenthood and self-characterization as a father" as well as the participants' and their partner's opinions on early paternal involvement (categories "Opinion on the early paternal involvement" and "Opinion of the partner about the early paternal emotional involvement"). All the participants reported feeling accomplished and happy as fathers:

"How do I feel as a father... I feel... I feel I'm the happiest man in the world..." (A4).

They characterize themselves as protective, understanding and a friend, always wanting to be present when needed:

"Hey... this one is hard... I think I'll be... am... protector, friend, loving... I want to have a close relationship with my son, be there when he needs me... I think that's it...” (A1).

All the participants mentioned that early paternal involvement is crucial not only for the development of the baby but also for the development of the father and stated that their partners also agreed that it is essential:

"I think it's very important for the development of the child and the development of the father as a father" (A1);

"She thinks it's necessary, crucial, she thinks the same way I do" (A4).

Finally, the participants reported "concerns about the health of the baby, clinical issues and medical involvement”, which included their concerns about the baby's health, medical issues and description of medical procedures, as well as the interaction with the medical staff:

"The caesarean section it was a complicated caesarean, is not a simple c-section because a child was almost six months... So it has its problems. They tried everything to save him, who was a new-born, a baby who was frail”" (A3). 


\section{DISCUSSION}

From the analysis of the interviews, it was possible to determine that these fathers had a strong desire for parenthood even though it was not always associated with the planning of the pregnancy. It is important to say that the reactions of happiness and joy concerning parenthood seem to have led them to an early involvement with their babies. According to several authors, the affective involvement of fathers with their child is built from the pregnancy onwards (Figueiredo, 2005; Martin, McNamara, Milot, Halle, \& Hair, 2007; White, Wilson, Elander, \& Persson, 1999) and depends on factors such as the relationship model established with the family of origin (Beaton \& Doherty, 2007) and/or the ambition of being a father (Magnusson \& Lapane, 2009).

Even though all participants shared a strong desire for fatherhood, there seems to have been an inability of imagining and fantasizing the baby by two of the participants. This creative process may have been somewhat disabled by problems some men had in becoming involved with the baby during pregnancy (Piccinini, Silva, Gonçalves, Lopes, \& Tudge, 2004). In the remaining fathers, there seems to have been an idealization of an almost perfect child, without any problem and/or health issues.

Moreover, the perspective of fatherhood also seems to have created feelings of doubt and fear in the interviewees. The transition towards fatherhood seems to be built through a multifaceted and ambivalent period, marked by difficulties and antagonisms (Gomez, 2005; Levy-Shiff, 1994) which, in this particular case, may have been due to difficulties experienced during the pregnancy and that ended up leading to the pre-term birth. The need to overcome problems and conform to the situation of hospitalization was mentioned by two of the fathers, who also presented some apprehension and fear regarding the future of the baby, and a strong desire for the baby's recovery. Nevertheless, the majority of the fathers interviewed mentioned feelings of satisfaction and happiness.

The literature stated that fatherly involvement is determined by different reasons (Bouchard, Catherine, Asgary, \& Pelletier, 2007). Based on the analysis of the four conditioning factors of the father's involvement with his child that were listed by Lamb et al. (1985), we seem to have the necessary conditions for the men interviewed to establish a relationship of proximity and envelopment with their preterm babies. A sharing of responsibility in terms of fatherly involvement also seems to exist, in that two factors are inherent to the father (Motivation and Self-confidence). The other two aspects do not belong to his will and ability (Support and Institutional Practices). Nevertheless, the participants were all romantically involved with their partners, this relationship was, however, somewhat idealized by the interviewees. The couple's relationship was one that supported and encouraged the father's participation. The relationship with the rest of the family was classified as good by most of the participants, which can be explained mainly through the need for isolation of the couple in their relationship, and/or by situations of geographical distance (two participants were foreigners).

Even though all the levels are equally important and dependent on each other, we have to underline the men's motivation to participate and get involved. In our sample this became very clear, as the categories related to the interaction with the baby were the ones that 
presented the highest frequency of r.u.. This result seems to be in accordance with what was reported by Henwood and Procter (2003), who indicate that the interviewees in their study gave a great importance to what they call the "new model of fatherhood", which is characterized by a caring, participative and nurturing father, who puts the child's needs first. This new fatherhood perspective enabled the participants to view themselves in a different way, liberated from the social constraints their own fathers had been under and, thus, being able to be a "full family member" and socially valued as fathers (Henwood \& Procter, 2003).

Overall, the evaluation of the fatherly involvement (Cabrera \& Tamis-LeMonda, 2000; Lamb et al., 1985) can be classified as positive in this study. Despite the differences between the five fathers, they were all willing to interact and get involved with the preterm baby. In addition, all these individuals demonstrated being fully available and responsible for their children. All five interviewees talked about themselves as present fathers, with the need to establish an emotional and close relationship with their babies, presenting not only of a desire for contact and proximity with the new-born, but also of affective involvement, showing interest and the need to participate in activities related to their children.

Contrary to other studies (e.g. Henwood \& Procter, 2003), the participants hardly mentioned monetary concerns, or trouble in reconciling work and family life. We believe this might be due to the specific context of this study, being the major concerns about the baby's health and survival.

It further important to mention that, although hospitalization is a moment of family crisis (Deeney, Lohan, Parkes, \& Spence, 2009) with a high risk of disturbing paternal adaptation (Pedrosa, Canavarro, Oliveira, Moura Ramos, \& Monteiro, 2005) and parental involvement with the preterm baby (Fegran et al., 2008), this particular situation seems to offer the father specific conditions that strengthen the development of his relationship with the child (Lindberg et al., 2008). Therefore, a common and equal space for the contact and interaction of the parents with the new-born exists, as well as a special kind of attention to the father figure from the medical staff in these types of units. Men receive additional support, both in terms of attention and incentive to participate as well as in terms of psychological support in this initial period of transition into fatherhood.

It is equally relevant to mention that only one of the fathers talked about the need to conceal his own feelings in order to support his partner. Many men do not allow themselves to share their anxiety and fear during this period because they feel the need and/or obligation to protect their partner (O'Leary \& Thorwick, 2006; Peterson, 2008). However, he fathers interviewed seemed to have a desire to be heard, expressed by the need to talk and the willingness to participate in the current study (Lundqvist \& Jakobsson, 2003; Olin \& Faxelid, 2003).

Early intervention in a family with premature babies can therefore have crucial importance, allowing for the possible recovery and better adaptation and learning in the event of preterm delivery (Carter, Mulder, Bartram, \& Darlow, 2005;Jotzo \& Poets, 2005; Tracey, 2000). Moreover, these initiatives to involve fathers need to consider both the ambivalent feelings about fatherhood and masculinity that arise, and the complex ways in which ideas of 'good' fathering are associated with gender (Robb, 2004), in order to promote a better paternal involvement. 
The condition of hospitalization due to preterm birth seems to be a situation that while difficult and anxious for the parents, also offers contact and involvement possibilities for the father in regard to his new-born. Even though the early involvement is mainly described as limited and insufficient, it also seems to have major importance in the later involvement of the father with the baby after the hospitalization period (Brazy, Anderson, Becker, \& Becker, 2001). However, a greater understanding of the complex process of the father's involvement with the premature baby is needed in order to create effective policies and procedures that will uphold the best interests of the father and his family.

\section{Acknowledgements}

We would like to thank the Neonatology Unit at São Francisco Xavier Hospital and the fathers that agreed to participate, for making this study possible. Furthermore, we would like to thank Filomena Valadão Dias for acting as an independent judge in the content analysis process.

\section{REFERENCES}

Adamsons, K., O’Brien, M., \& Pasley, K. (2007). An ecological approach to father involvement in biological and stepfather families. Fathering: A Journal of Theory, Research, \& Practice about Men as Fathers, 5, 129-147. doi: http://dx.doi.org/10.3149/fth.0502.129.

Arockiasamy, V., Holsti, L., \& Albersheim, S. (2008). Fathers' experiences in the neonatal intensive care unit: A search for control. Pediatrics 121, 215-222 doi: 10.1542/peds.20071005.

Bardin, L. (2008). Análise de conteúdo (4th ed.). Lisboa: Edições 70.

Beaton, J. M., \& Doherty, W. J. (2007). Fathers' Family of Origin Relationships and Attitudes about Father Involvement from Pregnancy through First Year Postpartum. Fathering: A Journal of Theory, Research, \& Practice about Men as Fathers, 5, 236-245. doi: 10.3149/fth.0503.236.

Bouchard, G., Catherine, M. L., Asgary, V., \& Pelletier, L. (2007). Fathers' motivation for involvement with their children: a self-determination theory perspective. Fathering: $A$ Journal of Theory, Research, \& Practice about Men as Fathers, 5, 25-41. doi: 10.3149/fth.0501.25.

Brazy, J., Anderson, B., Becker, P., \& Becker, M. (2001). How parents of premature infants gather information and obtain support. Neonatal Network: The Journal of Neonatal Nursing, 20, 41-48. doi: 10.1891/0730-0832.20.2.41.

Cabrera, N. J., \& Tamis-LeMonda, C. S. (2000). Fatherhood in the Twenty-First Century. Child Development, 71, 127-136. doi: 10.1111/1467-8624.00126.

Camus, J. L., \& Frascarolo, F. (2003). Introduction of the special issue on fatherhood. European Journal of Psychology of Education, 18, 95-99. doi: 10.1177/036319909902400301 
Carter, J. D., Mulder, R. T., Bartram, A. F., \& Darlow, B. A. (2005). Infants in a neonatal intensive care unit: parental response. Archives of Disease in Childhood - Fetal \& Neonatal Edition, 90, F109-F113. doi: 10.1136/adc.2003.031641.

Deeney, K., Lohan, M., Parkes, J., \& Spence, D. (2009). Experiences of fathers of babies in intensive care. Paediatric Nursing, 21, 45-47. doi: org/10.7748/paed2009.02.21.1.45.c6913.

Fägerskiöld, A. (2006). Support of fathers of infants by the child health nurse. Scandinavian Journal of Caring Sciences, 20, 79-85. doi: 10.1111/j.1471-6712.2006.00383.x.

Fägerskiöld, A. (2008). A change in life as experienced by first-time fathers. Scandinavian Journal of Caring Sciences, 22, 64-71. doi: 10.1111/j.1471-6712.2007.00585.x.

Featherstone, B. (2004). Fathers matter: A research review. Children \& Society, 18, 312-319. doi: org/10.1002/chi.842.

Fegran, L., Helseth, S., \& Fagermoen, M. S. (2008). A comparison of mothers' and fathers' experiences of the attachment process in a neonatal intensive care unit. Journal of Clinical Nursing, 17, 810-816. doi: 10.1111/j.1365-2702.2007.02125.x.

Feldman, R., Weller, A., Sirota, L., \& Eidelman, A. I. (2003). Testing a Family Intervention Hypothesis: The Contribution of Mother-Infant Skin-to-Skin Contact (Kangaroo Care) to Family Interaction, Proximity, and Touch. Journal of Family Psychology, 17, 94-107. doi: 10.1037/0893-3200.17.1.94.

Figueiredo, B. (2005). Bonding pais-bebé. In I. Leal (Ed.), Psicologia da Gravidez e da Parentalidade (pp. 287-306). Lisboa: Fim de século.

Ford, J. J., Nalbone, D. P., Wetchler, J. L., \& Sutton, P. M. (2008). Fatherhood: How differentiation and identity status affect attachment to children. American Journal of Family Therapy, 36, 284-299. doi: 10.1080/01926180701647074.

Gomez, R. (2005). O pai. Paternidade em transição. In I. Leal (Ed.), Psicologia da Gravidez e da Parentalidade (pp. 257-285). Lisboa: Fim de século.

Henwood, K. L., \& Procter, J. (2003). The 'good father': Reading men's accounts of paternal involvement during the transition to first time fatherhood. British Journal of Social Psychology, 42, 337-355. doi: org/10.1348/014466603322438198.

Hossain, Z., Roopnarine, J. L., Ismail, R., Hashmi, S. I., \& Sombuling, A. (2007). Fathers' and Mothers' Reports of Involvement in Caring for Infants in Kadazan Families in Sabah, Malaysia. Fathering: A Journal of Theory, Research, \& Practice about Men as Fathers, 5, 58-72. doi: 10.3149/fth.0501.58.

Jotzo, M., \& Poets, C. F. (2005). Helping parents cope with the trauma of premature birth: An evaluation of a trauma-preventive psychological intervention. Pediatrics, 115, 915-919. doi: 10.1542/peds.2004-0370.

Lamb, M. E. (1986). The changing roles of fathers. In M. E. Lamb (Ed.), The father's role: applied perspectives (pp. 3-27). New York: Wiley.

Lamb, M.E., Orbahc, Y., Hershkowitz, I., Esplin, P., \& Horowitz, D. (2007). A structural forensic interview protocol improves the quality of informativeness of investigative interviews with children: A review of research using the NICHD Investigative Interview Protocol. Child Abuse and Neglect, 31, 1201-1231. doi: org/10.1016/j.chiabu.2007.03.021.

Lamb, M. E., Pleck, J. H., \& Charnov, E., L. (1985). Paternal behavior in humans. American Zoologist, 25, 883-894. doi: org/10.1093/icb/25.3.883. 
Lau, R., \& Morse, C. A. (2003). Stress experiences of parents with premature infants in a special care nursery. Stress \& Health: Journal of the International Society for the Investigation of Stress, 19, 69-78. doi: 10.1002/smi.964.

Leal, I. (2008). A entrevista psicológica, Técnica, Teoria e Clínica. Lisboa: Fim de Século.

Levy-Shiff, R. (1994). Individual and contextual correlates of marital change across the transition to parenthood. Developmental Psychology, 30, 591-601. doi: 10.1037/00121649.30.4.591

Liebman, S. J., \& Abell, S. C. (2000). The Forgotten Parent No More: A Psychoanalytic Reconsideration of Fatherhood. Psychoanalytic Psychology, 17, 88-105. doi: 10.1037/0736-9735.17.1.88.

Lindberg, B., Axelsson, K., \& Öhrling, K. (2008). Adjusting to being a father to an infant born prematurely: experiences from Swedish fathers. Scandinavian Journal of Caring Sciences, 22, 79-85. doi: 10.1111/j.1471-6712.2007.00563.x.

Lundqvist, P., \& Jakobsson, L. (2003). Swedish men's experiences of becoming fathers to their preterm infants. Neonatal Network: The Journal of Neonatal Nursing, 22, 25-31. doi: 10.1891/0730-0832.22.6.25.

Magnusson, B., \& Lapane, K. (2009). Fathers’ pregnancy intentions. Perspectives on Sexual and Reproductive Health 41, 132-133. doi: 10.1363/4113209.

Martin, L. T., McNamara, M. J., Milot, A. S., Halle, T., \& Hair, E. C. (2007). The Effects of Father Involvement during Pregnancy on Receipt of Prenatal Care and Maternal Smoking. Maternal \& Child Health Journal, 11, 595-602. doi: 10.1007/s10995-007-0209-0.

McBride, B. A., Dyer, W. J., Liu, Y., Brown, G. L., \& Hong, S. (2009). The differential impact of early father and mother involvement on later student achievement. Journal of Educational Psychology, 101, 498-508. doi: 10.1037/a0014238.

O'Leary, J., \& Thorwick, C. (2006). Fathers' Perspectives During Pregnancy, Postperinatal Loss. Journal of Obstetric, Gynecologic, \& Neonatal Nursing: Clinical Scholarship for the Care of Women, Childbearing Families, \& Newborns, 35, 78-86. doi: 10.1111/j.15526909.2006.00017.x.

Olin, R.-M., \& Faxelid, E. (2003). Parents' needs to talk about their experiences of childbirth. Scandinavian Journal of Caring Sciences, 17, 153-159. doi: 10.1046/j.14716712.2003.00105.x.

Oliveira, R. V., Maroco, J., \& Pais, L. G. (2012). The Origin of Maltreatment: An exploratory study on the intergenerational transmission of child abuse typologies. Interdisciplinaria, 29, 253-269.

Pedrosa, A., Canavarro, M. C., Oliveira, C., Moura Ramos, M., \& Monteiro, S. (2005). Prematuridade e transição para a parentalidade: comparação da percepção de stress e impacto emocional em mães e pais de bebés prematuros. Iberpsicologia, 10, 2-7.

Pestvenidze, E., \& Bohrer, M. (2007). Finally, daddies in the delivery room: Parents' education in Georgia. Global Public Health, 2, 169-183. doi: 10.1080/17441690601054330.

Peterson, S. W. (2008). Father surrogate: historical perceptions and perspectives of men in nursing and their relationship with fathers in the NICU. Neonatal Network: The Journal of Neonatal Nursing, 27, 239-243. doi: 10.1891/0730-0832.27.4.239. 
Piccinini, C. A., Silva, M. R., Gonçalves, T. R., Lopes, R., S., \& Tudge, J. (2004). O envolvimento paterno durante a gestação. Psicologia Reflexão e Crítica, 17, 303-314. doi: org/10.1590/S0102-79722004000300003

Premberg, Å., Hellström, A.-L., \& Berg, M. (2008). Experiences of the first year as father. Scandinavian Journal of Caring Sciences, 22, 56-63. doi: 10.1111/j.14716712.2007.00584.x.

Ringler, N., Trause, M. A., Klaus, M., \& Kennell, J. (1978). The Effects of Extra Postpartum Contact and Maternal Speech Patterns on Children's IQs, Speech, and Language Comprehension at Five. Child Development, 49, 862-865. doi: 10.1111/14678624.ep10427390.

Robb, M. (2004). Exploring fatherhood: masculinity and intersubjectivity in the research process. Journal of Social Work Practice, 18, 395-406. doi: org/10.1080/0265053042000314456.

Ross, J. M. (1979). Fathering: A Review of Some Psychoanalytic Contributions on Paternity. International Journal of Psycho-Analysis, 60, 317-327.

Simões, R., Leal, I., \& Maroco, J. (2010). Envolvimento paterno de pais de crianças em idade escolar. In I. Leal \& J. Pais-Ribeiro (Eds.), Psicologia da Saúde: Sexualidade, Género e Saúde. Lisboa: ISPA.

Tracey, N. (2000). Parents of premature children - their emotional world. London: Whurr Publishers.

White, M. A., Wilson, M. E., Elander, G., \& Persson, B. (1999). The Swedish Family: Transition to Parenthood. Scandinavian Journal of Caring Sciences, 13, 171-176. doi: org/10.1080/02839319950162534. 